\title{
Targeting Sanitary Towel at Female Polytechnic Students: Exploring Television Advertising as an Intrusive Communication Tool
}

\author{
Samuel Sunday ELEBODA \\ Department of Administration and Management, College of Business and Social Sciences, \\ Crawford University, Faith City,, Igbesa, Nigeria \\ BAKO, ZAINAB FUNKE \\ Department of marketing, The Federal Polytechnic, Ilaro, Ogun State
}

\begin{abstract}
Advertising is one of the marketing tools aimed at creating awareness about a product to both the potential and actual consumers of such product. Many organizations in recent times have invested so much in advertising using the television medium. However, the efficacy of this medium of advertising is subjected to the interest of the viewers as most of the viewers may not like the idea of intruding into their other 'interesting' programmes. This paper examined the relationship between television advertising of sanitary pads and the purchasing behavior of the female users. The study's population consisted of female students of polytechnics in Ogun State. However, the targeted population were female students of three selected polytechnics namely; Federal Polytechnic, Ilaro; Moshood Abiola Polytechnic, Ojere, Abeokuta; and ICT Polytechnic, Itori with combined female students' population of 7,618. A sample of 199 of the students was taken based on Yamani formula and served with questionnaire as the tool for data collection. 144 copies of the questionnaire were retrieved and used for the data analysis. The quantitative data were analyzed using descriptive statistics while regression and correlation statistical tools were used to test the hypothesis of the study. The findings showed that there is a significant but weak linear relationship between television advertising and the buying behaviour of the female students $(\mathrm{r}=0.187, \mathrm{P}<0.05)$, and that television advertising accounted for only roughly $12.8 \%$ of the changes in buying behavior of the female students studied $\left(\mathrm{R}^{2}=0.128, \mathrm{P}<0.05\right)$. The study concluded that exposure to television advertising has influence on the patronage of sanitary pad brands. The study therefore recommends that manufacturers of sanitary pads should invest more in television advertising that are creative, informative and rich in content.
\end{abstract}

Keywords: Television Advertising, Intrusive Communication, Buying Behaviour, Sanitary Towel, Female Students, Media Exposure

DOI: $10.7176 / \mathrm{JMCR} / 69-04$

Publication date:July $31^{\text {st }} 2020$

\section{Introduction}

Staying clean during menstrual cycles is a primary responsibility of females as they approach puberty and begin to secrete relevant hormones. It is a common practice that has been in existence for the young females to be tutored on staying hygienic and the method to adopt. In the time past, it is not uncommon to find women who use rags to stay clean but today majority of females of menstruating age use sanitary pads to stay clean, especially ladies in the urban centres and particularly among girls of school age. As a response to this development, there are many brands of sanitary brands by different manufacturers out there in the Nigerian market. Each of these manufacturers, in response to stiff competition, most times relies on advertisement and other promotional activities to position their brand effectively in the minds of the consumers.

In the words of Arens and Bovee, (2000), advertising is basically the dissemination of sales messages through purchased space, time or other media. It is one of the marketing tools used by businessmen and women to promote their goods and services. Just as the media of social communication have enormous influence everywhere, so does advertising which uses the media as a vehicle for persuasion as well as a powerful force for shaping attitudes and behaviour in today's world. Individuals are exposed each day to a tremendous number of advertising stimuli. To cope with this enormous number of adverts, our sensory organs particularly the eyes, ears, etc, select those stimuli to which attention is given (Wells \& LoSciuto, 1966). Advertising is principally undertaken for persuasion or advocacy using media that are paid for, to get through to the mass audience with the identity of advertisers being clear (Arans \& Bovee, 2000).

Advertising is important because it influences audiences by informing or reminding them of the existence of a brand or alternatively by persuading or helping them differentiate a product from others in the market (Karen et. al., 2011). Advertising can reach a wide range of audiences with simple messages that announce the availability and location of products, express their quality and value, brands with personality and simultaneously define the personality of people who can buy them (Arans \& Bovee, 2000). Some of the key roles of advertising are; building 
awareness, inducing dialogue and positioning or repositioning brands by changing either perception or attitudes (Karen et. al., 2011).

Though advertising through all media influences audiences, but television is one of the strongest mediums of advertising and due to its mass reach and visual components, it does not only influence individual's attitude, behaviour, lifestyle and exposure but also, in the long run, could even influence the culture of the country (Latif, Abideen \& Zain, 2011).

The coming of television broadcasting to Nigeria expectedly prompted diverse programs which ranged from politics and socials to entertainment, business and education. So, from the various programmes there was the need for advertisement in television broadcasting. Today, there exists different advertisement of sanitary pads which is a commodity that is widely used by women in many societies including Nigeria. Sanitary pad advertisement is not common and when they are available, it is for very few market leaders in the industry including Always, Joy, Lady Care, etc. Sanitary pads advertisements are hardly found for the majority of pads in the Nigerian market. It is rare to find television advertisement for sanitary pads like Lola pads, Body form pads, Diva cup pads, Ladysept, etc.

Despite the inherent benefits of television advertising, many authors have asked whether an advert does not deprive the product being advertised of the required attention since the viewer/readers' attention may be carried away by the programme. There is also the debate as to whether the liking of an advert is directly transferred or transferrable to the product being advertised. If this is true, to what extent can this be achieved? It is against this background that this research examined the buying behavior of female polytechnic students towards advertised sanitary pads after they have been exposed to television advertising. Therefore the extent to which television advertising influences the patronage and other buying behaviours of female students towards the advertised sanitary pads, and the perception and attitude of the students towards television advertisement generally are the gaps which this research tried to fill.

\section{LITERATURE REVIEW}

\subsection{Conceptual Review}

2.2.1 Advertising

Advertising may be defined as any paid form of non-personal communication about an organization, products, services, or ideas by an identified sponsor (Belch \& Belch, 2011). The paid aspect of this definition reflects the fact that the space and time for advertising a message must be bought, except on the basis of Public Announcement Service (PAS), whose advertising space or time is usually donated by the media organization. Belch and Belch (2011) furthermore expatiated on the non-personal component of advertising which means advertising involves mass media (radio, television, newspaper, magazines etc) that transmit a message to the large group of individuals, often at the same time. This non personal nature also means that there is generally no opportunity for immediate feedback from the audience or recipients (except in direct response advertising). Therefore, before the message is sent, the advertiser must consider how the audience will interpret and respond to it.

According to Sharma and Singh (2012, p15), 'Advertising is non-personal communication of information usually paid for and usually persuasive in nature about products, services or ideas by identified sponsors through various media. The main purpose of advertisement is to identify and differentiate one product from the other and to persuade consumers to buy that product in preference to another.

Arans and William (1998, p14) also defined advertisement as 'the structured and composed non-personal communication of information usually paid for and usually persuasive in nature about product (goods, services and ideas) by identified sponsors through various media'. But in opinion of the Advertising Association of America, 'advertising is a means of making known in other to sell goods and services'. This definition portrays advertising as the process concerned with much more than giving information alone but rather, 'made known in order to sell' (Karmen, 2006).

Also, the Institute of Practitioners in Advertising (IPA) United Kingdom noted that, 'advertising is the most persuasive possible selling message to the right prospect for the products, services, at the lowest possible cost'. Karmen and Kovacic (2006) in Pillal and Bagauathi (2009) defined advertising ' as an art, science and technology of effective planning, execution and dissemination of factual information for the sales of goods and services in a persuasive manner that makes direct impact on the prospect for a favorable response'.

In conclusion, Advertisement means the art of making known and available a product for the consumer. And this is usually done with a persuasive, educative, informative, dramatic or colorful images expressed through different mass media. Such a product could be entirely new or a repackaged one from an existing producer through mass media such as; radio, television, magazines, websites, internets, town criers, gong, posters etc.

\subsubsection{Functions of Advertising}

According to Sambe (2005), the functions of advertising are numerous. Advertising plays a unique and central role in every economic system. Along with other forms of marketing communication, it helps to sell ideas, goods and services. Advertising reflects and effects our very life style and particularly, since advent of television, features prominently in political decisions. Advertising serves many communication needs of the society, including needs 
other than goods and services. It serves business firms, labour unions, government agencies and political leaders. Advertisement helps to inform and persuade pre-selected audiences about issues. Advertising informs the consumer so that more intelligent choices are made in the market place. Thus, advertising aids the competitive process. Advertising induces the firms' cost of production per unit of output. Thus, substantial plant economics or economies of scale are achieved, while fixed costs are spread over a large number of outputs. So advertising leads to a more efficient use of resources in the economy. Through advertising, new firms have an easier time entering the market than would be through if advertising were restricted or prohibited. Advertising helps new firms, or firms with new products take on the giants in the industry and carve out a niche for themselves in the market place. Thus advertising again is precompetitive.

Advertising helps fuel the economy by motivating buyers and supporting sellers. It is typically used in conjunction with other promotional tools like personal selling, sales promotion and public relations and it is the heart of marketing strategy for most consumer goods.

According to Amy (2011), advertising influences people through education, persuasion and reassurance. It also influences the shopping experience; by making shopping simpler and helping to moderate the prices of advertised products.

\subsubsection{Education}

In Amy's view, Advertising offers an effective means of communicating information about product and services to a large number of consumers at once. This information plays a key role in educating people about different brands, functions and features like; how such brands work; what they cost, and where they can be purchased because the information in advertisement comes directly from the manufacturer, it is more likely than separate report to be verifiable and reliable. This helps buyers make choices most likely to satisfy their needs and wants.

\subsubsection{Persuasion}

Using creative techniques like direct brand comparisons, advertising can persuade people that one product will be better than another in improving their lives or delivering benefits they seek. It can often motivate them to take immediate actions like trying a new brand, redeeming a coupon, or requesting more information by calling attention to different uses of a product. Advertising also encourages people to buy in bigger volumes and/or more frequently than they otherwise would.

\subsubsection{Reassurance}

Before a buyer completes her purchase, advertising can effectively help her confirm that she is getting value for what she wants. Even after transaction has been made, advertising places a role by reminding a consumer why she spent her money and reassuring her that she made the right choice. This reassurance effect of advertising is especially important when the product is expensive or the choice becomes risky. In other words, it helps to eliminate the psychological discomfort commonly known as "buyer's remorse".

\subsubsection{Television Advertising}

Advertising has become one of the prime sources of generating income for companies and institutions, the media as well as government. Without advertisement, many businesses may have collapsed by now (Arans \& Bovee, 2000). As a result, advertisements have become very common in Nigeria, the television stations, the radio, and all other media outlets are dominated by advertisement on various products. Due to the fact that a television commercial combines sight, sound, and motion, they are more dramatic than any other form of advertising and they tend to excite and appeal to ordinary people, sometimes due to humour that is involved.

Humor in television advertisement has made many advertisement campaigns widely popular, in some cases, achieving the status of folklore or taking new life in another arena (Arans \& Bovee, 2011). The mass media, such as television plays an important role in influencing viewers by communicating values and behaviour. In addition, television advertisement may be regarded as best and the most effective medium in advertising products, ideas, goods and services. This is because advertisement helps the viewers and buyers to gain more knowledge, information, insight, and in fact come in contact with the product from a distance unlike other means of advertisement.

\subsection{Theoretical Framework}

\subsubsection{Media Dependency Theory}

The theory propounded by Ball, Roacheach and Defleur (1976) as cited in Anaeto, , Onabanjo, and Osifeso (2008) states that the more an individual depends on media, (i.e television) for having his or her needs fulfilled, the more this will become more to the person. In other words, the more an individual depends on media to get information and messages, the more the media will be part of the person's life. For instance, the empirical study of Manimala and Makunda (2004) revealed that teenagers liked television commercials because they derive entertainment and information from it. Fishbein and Ajzenl, (1975) developed media dependency theory in 1976, and the key ideas of the theory include;

a) Audience depends on media information to meet and reach goals.

b) Social institutions and media systems interact with audiences to create needs, interests and motives in the person. 
The relationship between media dependency theory and this study lies in the fact that consumers depend on media information to meet certain goals. So, sanitary pad manufacturers seek to use media advertisement to persuade, educate and inform buyers about their products. Consumers' reliance on media may increase, thereby shaping their beliefs, exposure and knowledge which will later reflect in their choices and buying behaviours (Little John \& Foss, 2008).

\subsection{Empirical Review}

Manimala and Makunda (2004) explored the nature of interface between television advertising and its outcome of responses from consumers. The study took students from age $15-25$ years, both males and females from urban and rural areas of Kerala. The study found that almost $100 \%$ of students were in the habit of watching television regularly. Generally, the respondents showed a lot of interest in television advertisement. A large majority (85\%) stated that they liked television advertisement. In conclusion, overexposure, irritating presentations and lack of involvement in the product were pointed out as the main reasons for disliking a television advertisement.

Odia and Oamen (2013) in their study submitted that television advertisement has great impact on product marketing, while Awofadeju (2015) opined that advertising helps to build demand for those products that are doing well and help to locate buying interest in new and old products. Advertising is also used to locate a product, a repeat purchase, increases sales, increases profit, breaking brand loyalty etc.

Shanthi and Ashok (2016) in their study of TV advertisement of cosmetics and the buying behavior of college going girls in selected cities of Tamilnadu, India suggested that Television and advertising together present a lethal combination and has become an integral part of modern society. They concluded that attractive advertisements instigate the purchasing habit and selection of various brands of the product based on need and their satisfying capacity. Advertisements have more influence on the buying behavior of girl students more particularly the cosmetic goods on reasons of their assured special features (Manickam \& Ceasar, 2016).

\section{Methodology}

The research design adopted for the study is the survey design which allows information to be obtained from the people through asking relevant questions. It was conducted in 3 Polytechnics in Ogun State namely: Federal Polytechnic, Ilaro, Moshood Abiola Polytechnic, Ojere, Abeokuta and ICT Polytechnic, Itori. The target population therefore consisted of female students of these polytechnics with a population of seven thousand six hundred and eighteen $(7,618)$ female students: Federal Polytechnic, Ilaro $(3,143)$, Moshood Abiola Polytechnic, Ojere $(3,235)$ female students and Adegbenro ICT Polytechnic $(1,240)$. The sample size for the study was determined using Taro Yamane sampling formula as follows:

$$
\mathrm{n}=\frac{\mathrm{N}}{1+\mathrm{N}(\mathrm{e})^{2}}
$$

Where:

$$
\begin{array}{ll}
\mathrm{N}= & \text { Population } \\
\mathrm{n}= & \text { Sample Size } \\
\mathrm{e}= & \text { Percentage of margin }
\end{array}
$$

Therefore,

$$
\begin{aligned}
\text { re, } & \mathrm{n}=\frac{7618}{1+7618(0.07)^{2}} \\
& =\frac{7618}{1+7618 \times 0.0049} \\
& =\frac{7618}{1+37.33} \\
& =\frac{7618}{38.33} \\
\mathrm{n}= & 199 \text { Respondents }
\end{aligned}
$$

One hundred and ninety-nine (199) respondents were therefore sampled. Simple random sampling method was adopted in selecting students from the population of female students in each polytechnic to arrive at the sample size of 199 for the study. This helped to ensure that every female student in each school had an equal chance of being selected.

The data for the research were obtained from both primary and secondary sources. The primary data were collected with the use of questionnaire. The secondary data were obtained through publication about television advertising and customer buying behaviour available on the internet, magazine etc. and the data collected were analyzed with simple regression. The regression equation for determining the effect of television advertising on consumer buying behaviour was set as follow:

$$
\mathrm{Y}=\mathrm{f}(\mathrm{X})
$$

Where: 
$\mathrm{Y}=$ Consumer Buying Behaviour $(\mathrm{CBB})$

Therefore;

$\mathrm{X}=$ Television Advertising, (TA)

$\mathrm{CBB}=\beta_{0}+\beta_{1} \mathrm{x}_{1}+e$

Therefore:

$\mathrm{CBB}=\beta_{0}+\beta_{1}(\mathrm{TA})+\mathrm{e}$

Where:

$\beta_{0}=$ intercept

$\beta_{1}=$ slope

$\mathrm{e}=$ error term

\section{Discussion of Findings}

A total of one hundred and ninety-nine (199) copies of the questionnaire were distributed to female students of the three polytechnics in Ogun state out of which one hundred and forty-four (144), representing 72.36\%, were returned. The following tables were generated from the data collected:

Table 4.1: Frequency Table in Respect of the Demographic Variables of the Respondents

\begin{tabular}{|l|r|r|r|r|}
\hline & Frequency & \multicolumn{1}{|c|}{ Percent } & \multicolumn{1}{c|}{ Valid \% } & Cumulative Percent \\
\hline Fed. Polytechnic, Ilaro & 53 & 36.8 & 36.8 & 36.8 \\
\hline Adegbenro Polytechnic, Itori & 42 & 29.2 & 29.2 & 66.0 \\
\hline Moshood Abiola Polytechnic, Ojere & 49 & 34.0 & 34.0 & 100.0 \\
\hline Total & 144 & 100.0 & 100.0 & \\
\hline
\end{tabular}

\section{Source: Field Survey, 2018}

Table 4.1 above shows that out of the 144 respondents that participated in the study, $53(36.8 \%)$ were from the Federal Polytechnic, Ilaro, 42 (29.2\%) were selected from Adegbenro Polytechnic, Itori, while 49 (34\%) were from Moshood Abiola Polytechnic, Abeokuta. This shows that attempt was made to ensure that the sample sizes reflected the population of female students in each institution, given that the study's samples consisted of almost equal numbers of female students.

\begin{tabular}{|l|l|r|r|r|r|}
\hline \multicolumn{2}{|l|}{ Table 4.2: Age Bracket } & Frequency & Percent & Valid Percent & Cumulative Percent \\
\hline \multirow{3}{*}{ Valid } & $15-20$ years & 59 & 41.0 & 41.8 & 41.8 \\
\cline { 2 - 6 } & $21-25$ Years & 70 & 48.6 & 49.6 & 91.5 \\
\cline { 2 - 6 } & 26-30 Years & 11 & 7.6 & 7.8 & 99.3 \\
\cline { 2 - 6 } & 31 years and above & 1 & .7 & .7 & 100.0 \\
\cline { 2 - 7 } & Total & 141 & 97.9 & 100.0 & \\
\hline Missing & 99 & 3 & 2.1 & & \\
\hline Total & 144 & 100.0 & & \\
\hline
\end{tabular}

\section{Source: Field Survey, 2018}

Table 4.2 is on age brackets of the respondents and it shows that out of the 144 respondents, $59(41 \%)$ were aged between 15-20 years, $70(48.6 \%)$ were aged between 21 and 25 years, $11(7.6 \%)$ were aged between 26 and 30 years, and only $1(0.7 \%)$ was aged above 30 years. This shows that majority of the respondents were aged below 26 years, and this represents the situation in the institutions as students at that level are most likely to be teenagers and early twenties.

\section{Table 4.3a: Model Summary}

Model

$\mathrm{R}$

R Square

Adjusted R Square

Std. Error of the Estimate

\begin{tabular}{lrrrr}
\hline 1 & $.187^{\mathrm{a}}$ & .135 & .128 & 2.852 \\
\hline
\end{tabular}

a. Predictors: (Constant), Television Advertising

Author's Computation, 2018

Table 4.3b: ANOVA

\begin{tabular}{llr|r|r|r|r} 
Model & Sum of Squares & Df & Mean Square & F & Sig. \\
\hline \multirow{2}{*}{1} & Regression & 41.904 & 1 & 41.904 & 5.152 & $.025^{\text {b }}$ \\
\cline { 2 - 8 } & Residual & 1154.985 & 142 & 8.134 & & \\
\cline { 2 - 8 } & Total & 1196.889 & 143 & & &
\end{tabular}

a. Dependent Variable: Consumer Buying Behaviour

b. Predictors: (Constant), Television Advertising

Author's Computation, 2018 


\begin{tabular}{|c|c|c|c|c|c|c|}
\hline \multicolumn{7}{|c|}{ Table 4.3c: Coefficients ${ }^{\mathrm{a}}$} \\
\hline \multirow{2}{*}{\multicolumn{2}{|c|}{ Model }} & \multicolumn{2}{|c|}{ Unstandardized Coefficients } & \multirow{2}{*}{$\begin{array}{c}\text { Standardized Coefficients } \\
\text { Beta }\end{array}$} & \multirow[b]{2}{*}{$\mathrm{T}$} & \multirow[b]{2}{*}{ Sig. } \\
\hline & & $\mathrm{B}$ & Std. Error & & & \\
\hline & (Constant) & 20.814 & 1.957 & & 10.638 & .000 \\
\hline & Television Advertising & .181 & .080 & .187 & 2.270 & .025 \\
\hline
\end{tabular}

a. Dependent Variable: Consumer Buying Behaviour

\section{Author's Computation, 2018}

Tables $4.3 \mathrm{a}, 4.3 \mathrm{~b}$, and $4.3 \mathrm{c}$ above present the results of the regression analysis in respect of the interaction between the dependent variable (Consumer Buying Behaviour) and the independent variable: (Television Advertising). Table $4.3 \mathrm{a}$ shows that the coefficient of determination $\mathrm{R}^{2}=0.135$ and adjusted $\mathrm{R}^{2}=0.128$ which implies that TA accounted for roughly $12.8 \%$ of the changes in CBB while the remaining $87.2 \%$ are accounted for by other variables not included in the model (otherwise called error term).

Tables $4.43 \mathrm{~b}$ and $4.3 \mathrm{c}$ show other results of the regression analysis. The F statistic in table $4.43 \mathrm{~d}$, which presents the model fit, shows that $\mathrm{F} 1,142=5.152, \mathrm{P}<0.05$ is significant, indicating that the model can predict the changes in the dependent variable given the explanatory variable. The contribution of Television advertising to a change in Consumer buying behavior is $\left(\beta_{1}=0.187 ; \mathrm{t}=2.270 ; \mathrm{P}=0.025\right)$, which is significant at $5 \%$ level of significance. We therefore reject the null hypothesis and accept the alternative and conclude that Television advertising has significant effect on the buying behaviour of female polytechnic students in Ogun State.

\begin{tabular}{|c|c|c|c|c|c|c|c|}
\hline & & & \multicolumn{4}{|c|}{ Exposure to Television Advertising (ETA) } & \multirow[t]{2}{*}{ Total } \\
\hline & & & Highly Unexposed & $\begin{array}{l}\text { Moderately } \\
\text { Unexposed }\end{array}$ & $\begin{array}{c}\text { Well } \\
\text { Exposed }\end{array}$ & $\begin{array}{c}\text { Highly } \\
\text { Exposed }\end{array}$ & \\
\hline \multirow[t]{9}{*}{ SPP } & Always & Count & 4 & 23 & 41 & 20 & 88 \\
\hline & & $\%$ within SPP & $4.5 \%$ & $26.1 \%$ & $46.6 \%$ & $22.7 \%$ & $100.0 \%$ \\
\hline & & $\%$ of Total & $2.8 \%$ & $16.2 \%$ & $28.9 \%$ & $14.1 \%$ & $62.0 \%$ \\
\hline & \multirow[t]{3}{*}{ Lady Care } & Count & 1 & 13 & 27 & 10 & 51 \\
\hline & & $\%$ within SPP & $2.0 \%$ & $25.5 \%$ & $52.9 \%$ & $19.6 \%$ & $100.0 \%$ \\
\hline & & $\%$ of Total & $0.7 \%$ & $9.2 \%$ & $19.0 \%$ & $7.0 \%$ & $35.9 \%$ \\
\hline & \multirow[t]{3}{*}{ Joy } & Count & 0 & 1 & 2 & 0 & 3 \\
\hline & & $\%$ within SPP & $0.0 \%$ & $33.3 \%$ & $66.7 \%$ & $0.0 \%$ & $100.0 \%$ \\
\hline & & $\%$ of Total & $0.0 \%$ & $0.7 \%$ & $1.4 \%$ & $0.0 \%$ & $2.1 \%$ \\
\hline \multirow{3}{*}{\multicolumn{2}{|c|}{ Total }} & Count & 5 & 37 & 70 & 30 & 142 \\
\hline & & $\%$ within SPP & $3.5 \%$ & $26.1 \%$ & $49.3 \%$ & $21.1 \%$ & $100.0 \%$ \\
\hline & & $\%$ of Total & $3.5 \%$ & $26.1 \%$ & $49.3 \%$ & $21.1 \%$ & $100.0 \%$ \\
\hline
\end{tabular}

\section{Author's Computation, 2018}

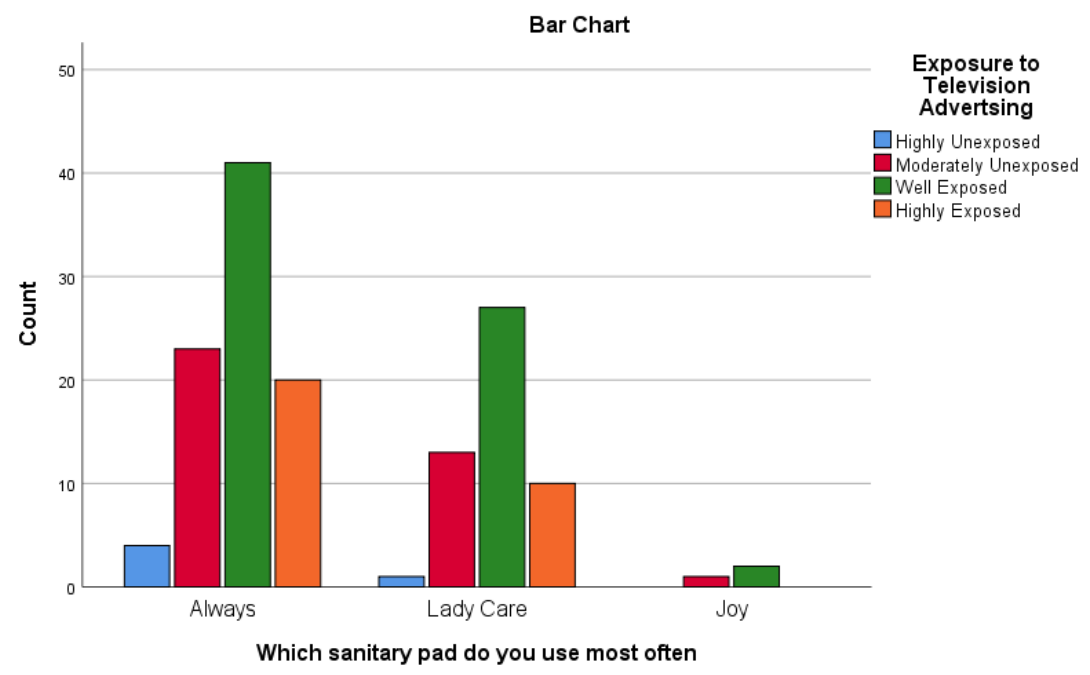

Author's Computation, 2018

Table 4.4 above, as well as figure 4.1 that follows present the analysis of the effect of exposure to television advertising on the choice of sanitary pads among the participants. The table shows that the highest percentage of those who patronized each brand were those well exposed to television advertising: For Always brand, 46.6\% ( $28.9 \%$ of the total), and $22.7 \%$ ( $14.1 \%$ of the total $)$ were well exposed and highly exposed to television advertising 
respectively. For Lady Care brand, $52.9 \%$ (19\% of the total), and $19.6 \%$ ( $7 \%$ of the total) were well exposed and highly exposed to television advertising respectively, while for Joy brand, $66.7 \%$ (or $1.4 \%$ of the total) and $0 \%$ (or $0 \%$ of the total), were well exposed and highly exposed to television advertising respectively. Overall, $49.3 \%$ and $21.1 \%$ of the participants who made brand purchases were exposed to television advertisements. We therefore conclude that exposure to television advertising has influence on the patronage of sanitary pad brands.

\section{Conclusions}

The study concludes that television advertising has significant effect on the buying behaviour of female polytechnic students in Ogun State, and the contribution of Television advertising to a change in buying behavior is $\left(\beta_{1}=0.187 ; \mathrm{t}=2.270 ; \mathrm{P}=0.025\right)$.

The study also concludes that there is a significant relationship between Television advertising and awareness creation in respect of sanitary pads among female polytechnic students in Ogun State, such that as television advertising increases or is enhanced, awareness of the advertised brand also increases with the likelihood of an increase in patronage.

We equally conclude that television advertising has significant effect on the brand preferences of female polytechnic students in Ogun State, and that manufacturers of sanitary pads can substantially improve the preference for their brands by advertising such brands on television.

Finally, the study concludes that exposure to television advertising has influence on the patronage of sanitary pad brands among female students.

Deriving from the data analyses, a large percentage of the respondents believe that television advertisement of sanitary pads is a very effective and interesting means of influencing their preference for their chosen brands. This is further confirmed by the buying choice of sanitary pad by female students from the selected polytechnics.

From the quantitative data analyzed, the study concludes that the power of the television medium greatly helps to promote products more than other media because of its visual and audio capabilities which enable it show and demonstrate the products, in terms of how to use it and differentiate it from other competitive brands.

Quality was the major factor that influenced the choice of sanitary pads while other factors such as Price, Friends/Family, Adverts, Packaging, and People effect had very low rating.

\section{Recommendations}

Deriving from the findings and conclusions of this study, the following recommendations are made:

i. Since it has been confirmed from this study that television advertising has significant effect on consumer buying behaviour, manufacturers of sanitary pads should reach out to potential and existing female customers through television adverts that are creative, informative, and rich in content.

ii. Also, the firms should place the advertisement of their brands in as many television stations as possible as a way of popularizing the product among prospective buyers in higher institutions in Nigeria.

iii. Television adverts should be aired regularly since the purchase of sanitary pads is a monthly exercise for majority of the sampled female students.

\section{REFERENCES}

Abayomi, O.T., Adebowale, A.O., \& Francis, D.S. (2012). The role of Personal selling in enhancing client satisfaction in Nigerian Insurance Market. Journal of Emerging Trends in Economics and Management Sciences, 3(2), 147-152.

Ademola, B.O. (2009). Effect of Consumers Mood on Advertising Effectiveness. Europe's Journal of Psychology, 4, 118-127.

Adler, P. (1980). The Effects of Television Advertising on Children, Lexington, MA: Lexington Books.

Akinfeleye, R. A., \& Okoye, I. E. (2003). Issues in Nigeria media history 1900-2000AD. Lagos: Malt House Press.

Amy, H. (2011). How does advertising influence people. Retrieved on June 52018 at http://www.ehow.comladvertising

Anaeto, S. G., Onabanjo, O. S., \& Osifesho, J. B. (2008). Models and theories of Communications. Bowie Maryland: African Renaissance books.

Aneeza, B., \& Najma, I.M. (2009). Effects of Advertising on Consumer Behavior of University Students. Proceedings from the $2^{\text {nd }}$ CBRC, Lahore, Pakistan, November 14, 2009.

Ansari, M. E., \& Joloudar, Y. E. (2011). An Investigation of TV Advertisement Effects on Customers'. International Journal of Marketing Studies, 175-181.

Arans, F. W., \& Bovee, C. L. (2000). Contemporary advertising 6th edition. New York: Richard D.Irwin.

Arans, W. F., \& William, F. (1996). Contemporary Advertising. U.S.A: Times mirror higher education group.

Atkin, C. K. (1982). Television advertising and socialization to consumer roles. In: D. Pearl (Ed.), Television and behaviour: Ten years of scientific progress and implications for the eighties (191-200). Rockland, MD: National Institute of Mental Health. 
Awofadeju, P.O., Taiwo, T.F., Akinrosoye, A.I., Philip, O.E., \& Adeagbo, S.A. (2015). The effect of television advertising on the success of a business organization. International Journal of Advanced Academic Research, 1(1), 1-19.

Ayanwale, E., \& Adeolu, B. (2005). The Influence of Advertising on Consumer Brand Preference. Journal of social Sciences, 10(5), 9-16.

Bari, A., \& Rana, Z.A. (2011). Advertisement \& Islam: A Muslim world perspective. Australian Journal of Business and Management Research, 1(6), 152-157.

Belch, G. E., \& Belch, A. M. (2011). Advertising and promotion, an integrated marketing perspective. New York: McGraw-Hill.

Bishnoi, V.K. \& Ruchi, S. (2009). The impact of TV advertising on buying behaviour: A comparative study of Urban and Rural teenagers. JK Journal of Management \& Technology, 1(1), 65-76.

Brace, I., \& Edwards, I. (2002). Can advertising reach everybody? Adweekly, July/August, 26-28.

Ciochetto, L. (2006). The dynamics of contemporary advertising in Thailand, Media Asia, 33(3), 185-191.

Clow, K.E., \& Baack, D.E. (2013). Integrated Advertising. London: Pearson Education Limited.

Colley, R.H. (1961). Marketing Information Guide. Office of Distribution, Business and Defense Services Administration, U.S. Department of Commerce, 8, 1-249.

Cotte, J., \& Wood, S.L. (2004). Families and innovative consumer behavior: A triadic analysis of sibling and parental influence. Journal of Consumer Research, 31, 78-86.

Defleur, M. C., \& Ball-Roacheach, S. J. (1989). Theories of mass communication ( $5^{\text {th }}$ edition).

Elena, S. M \& Banwari M. (2010) Advertising's new audiences. Journal of Advertising, 39(3), 8198, DOI: $10.2753 / \mathrm{JOA} 0091-3367390300$.

Fishbein, M., \& Ajzen, I. (1975). Belief, attitude, intention and behavior: An introduction to theory and research. Reading, MA: Addison-Wesley

Foxall, G. R., \& Goldsmith, R. E. (1994). Consumer psychology of marketing. Great Britain: Routledge Publishing.

Gerbner, G., Gross, L., Signorelli, N., \& Morgan, M. (1980). Aging with television: Images on television drama and conceptions of social reality. Journal of Communication Winter, 37-47.

Henderson, C. M., Robert K., Leslie I., \& Scott W. (1980). Influences on Children's Product Requests and Mother Answers: A Multivariate Analysis of Diary Data. Marketing Science Institute, Working Paper No. 80-108.

Hite R.E., \& Eck R. (2007). Advertising to children: Attitudes of business vs. consumers. Journal of Advertising Research, 27, 41-53

Jasmina Ilicic, C. M., \& Webster. (2011). Effects of multiple endorsements and consumer- celebrity attachment on attitude and purchase intention. Australasian Marketing Journal (AMJ), 19 (4), 230-237.

Jefkins, F., \& Yadin, D. (2006). Advertising Genesis, Evolution, Principle, Practice. Enugu: Snaap Press

Jennifer, L., John, H., Bargh \& Brownell, D. (2009). Priming effect of television food advertising on eating behavior. Yale University Journal, 28(4), 404-413.

Joel D. (1951). Advertising budget. Harvard Business Review, 29, 65-74.

Kadam, P., \& Bhalerao, S. (2010). Sample size calculation. International Journal of Ayurveda Research, 1(1), 55 57.

Karen L. B., Charles R. T., Hill, R. P., \& Yalcinkaya, G. (2011). A cross-cultural examination of corporate social responsibility marketing communications in Mexico and the United States: strategies for global brands. Journal of International Marketing, 19(2), 30-44.

Karmen E., \& Kovacic, M.P. (2006). Relations with the media: who are the main actors in an advertorial production process in Slovenia? Sage Journals, 11(1), 81-109.

Kaur, H., \& Kaur, R. (2002a, 2002b). Fashion awareness among rural and urban adolescents. Journal of Social Research, 43(1), 37-40.

Kirmani, A., \& Rao, A.R. (2000). No pain, no gain: a critical review of the literature on signaling unobservable product quality. Journal of Marketing, 64(2), 66-79.

Kishor, D. N. (2014). Rural consumer behaviour towards consumer Durable goods in India. International Journal of Advance Research in Computer Science and Management Studies, 2 (3), 1-14.

Kotler, P., Wong, V., Saunders, J., \& Armstrong, G. (2005) Principles of Marketing, fourth European Edition, Pearson Prentice Hall.

Kotwal, N., Gupta, N. \& Devi, A. (2008a, 2008b). Impact of T.V advertisements on buying pattern of adolescent girls. Journal of Social Science, 16 (1), 51-55.

Kumar, D.P., \& Raju, K.V. (2013). The role of advertising in consumer decision making. Journal of Business and Management, 14(4), 37-45.

Kumar, S.A., \& Madhavi, C. (2006). Rural marketing for FMCG, Indian Journal of Marketing, 36(4), 19-38.

Latif, A., Abideen, O., \& Zain, U. I. (2011). Advertising message perception. Lagos: media world, Diamond Publication.

Lavidge, R. C., \& Steiner, G. A. (1961). A model of predictive measurement of advertising effectiveness. Journal 
of Marketing, 59-62.

Leckeny, J. D. (1976). Conceptual foundations for copy testing research. Advertising Working Papers no. 2. USA: Unknown Publishers.

Liebeck, L. (1998). The customer connection: children under 13. Discount Store News October: 55-57.

Little-John, S. W., \& Foss, K. A. (2005). Theories of Human Communication. USA: Thompson. New York: Longman.

Loudon, L. D., \& Bitta, D. J. A. (1994). Consumer behavior (4th ed.). New York: McGraw Hill, Inc.

Manickam, P.S., \& Ceasar, M.J. (2016). TV advertisement of cosmetics and the buying behavior of college going girls in selected cities of Tamilnadu. Intercontinental Journal of Marketing Research Review, 4 (2), 213-219.

Manimala, S., \& Mukunda, V. (2004). Impact of Tv commercials (advertisement) on consumer 'purchase behaviour. Retrieved from http://www.thehindubusinessline.com/ 2004/03/26 /stories/ 2004032600671700.

Mayer, R. E. (2005). Cognitive theory of multimedia learning. In R. E. Mayer (Ed.), The Cambridge handbook of multimedia learning (pp. 31-48). New York: Cambridge University Press.

McGrath, J.M., \& Mahood, Chad. (2004). The impact of arousing programming and product involvement on advertising effectiveness. Journal of Current Issues \& Research in Advertising, 26(2), 4152, DOI: 10.1080/10641734.2004.10505163.

Meyer-Waarden L. \& Benavent C. (2009), Retail loyalty program effects: Self-selection or purchase behavior change? Journal of the Academy of Marketing Science, 37(3), 345-58.

Mickel O. (1990). The effect of TV. Ad. On Iraqi consumers. Master thesis, Iraq University.

Miglani J (2015). Forrester research social media forecast, 2015 to 2020 (US). Retrieved from: https://www.forrester.com .

Mooij, M.K., \& Keegan, W.J. (1994). Advertising worldwide: concepts, theories, and practice of International, Multinational, and Global advertising. Prentice Hall. ISBN: 9780134718972.

Morden, A., R. (1991), Elements of Marketing. London: D.P. Publication Lt.

Moschis, G. P. and Mitchell, L. G. (1986). Television Advertising and Interpersonal Influences on Teenagers Participation in Family Consumer Decisions. Advances in Consumer Research, 13,181-186.

Kundu, A., Kulkarni, P., \& Murthy, A. (2010). Advertising and Firm Value: Mapping the Relationship between Advertising, Profitability and Business Strategy in India. CHANGING IDEAS IN STRATEGY, Arun Sinha, ed., Narosa Publications, 2010.

Langheinrich, M., Nakamura, A., Abe, N., Kamba, T., \& Koseki, Y. (1999). Un-intrusive customization techniques for web advertising. Computer Networks 31, 1259-1272.

Namasivyam, K. \& Lin, I. (2008). The service scape. In Jones, P. (Ed.). The handbook of Hospitality Operation and IT (pp.43-62). NewYork: Elsvier Ltd.

Nazir, S. (2001). Effects of advertisement on consumer's behavior. Unpublished M.Sc. Research Report. National Institute of Psychology, Quaid-Azam University, Islamabad.

North, E.J., \& Kotze, T. (2001). Parents and Television advertisements as consumer socialization agents for adolescents: An exploratory study. Journal of Family Ecology and Consumer Sciences, 29, 91-99

Odia, P., \& Oamen, D. O. (2013). Television Advertising Impact on Female Production Marketing in Select Nigerian Schools: A Case Study of Always Ultra. International Journal of Case Studies, 2(4), 131-139.

Olsson, V., \& Larsson, A. (2005). Humor in Advertising. Bachelor's Thesis, Department of Business Administration and Social Sciences, Lulea University of Technology. ISSN: 1404-5508.

Pillal, R. S., \& Bagauathi, N. (2009). Modern Marketing Principles and Practice. India: Chad and Company limited.

Raju, D. D. (2013). The Role of Advertising in Consumer Decision Making. IOSR Journal of Business and Management (IOSR-JBM), 14 (4), 37-45.

Saksena,G. (1990). Advertising through T.V., social implications. Journal of Indian Institute of Mass Communication, 25(1): 44-49.

Sambe, J. A. (2005). Introduction to Mass Communication Practice in Nigeria. Lagos: Spectrum Books Limited.

Scott, J.D (1943). Advertising When Buying is Restricted. Harvard Business Review, 21(4), 443-454.

Sehrawet, M. \& Kundu, S. C. (2007). Buying behaviour of rural and urban consumers in India: the impact of packaging, International Journal of Consumer Studies, 31(6), 630-638.

Selvaraj A. (2007). Rural Consumers' Behaviour Regarding Non -Durable Goods: A Study in Erode District of Tamil Nadu. Indian Journal of Marketing, 37(12), 35-42.

Shahid, M. I. (1999). Mass communication (2nd Rev. ed.). Lahore: Carvan Press.

Shanthi, D., \& Ashok, K.M. (2016). Influence of Television advertisements on buying behaviour of rural and urban college girls. International Journal of Management, 7(7), 53-60.

Sharma, S., \& Singh, R. (2012). Advertising; Planning and Implementation. New Delhi: PHL Learning Private Limited.

Siddiqui, A. N. (2014). Tv Ads impact on Consumer Purchase Intention. International Conference on Marketing. 
Segal, U. A. (1998). Family violence: A focus on India. Aggression and Violent Behavior, 4(2), 213-231.

Swati B. (2013). Impact of TV advertisement on youth purchase decision - literature review. Journal of Research in Management \& Technology, 2(3), 213-219.

Udofia, E.P. (2011), Applied Statistics with Multivariate Methods. Immaculate Publications Limited, Enugu, 218.

Wells, D. W. \& LoSciuto, A. L. (1966). Direct observation of purchasing behavior. Journal of Marketing Research, 52(3), 227-233.

Wells, W., Burnett, J., \& Moriarty, S.E. (1999). Advertising: Principles \& Practice. London: Prentice Hall Inc.

Wilkie, W. L. (1994). Consumer behavior (3rd ed.). USA: John Wiley \& Sons, Inc.

Wilmshurst, J. (1985). The fundamentals of advertising. Singapore: Butterworth Heinemann.

Zhang, Y., \& Zinkhan, G.M.(1991). Humor in Television Advertising: the effects of Repetition and Social Setting. in NA - Advances in Consumer Research Volume 18, eds. Rebecca H. Holman and Michael R. Solomon, Provo, UT : Association for Consumer Research, Pages: 813-818. 